\title{
Research on the Influence of Farmers' Entrepreneurial Motivation on Entrepreneurial Performance
}

\author{
Qinjuan $\mathrm{Li}^{1, *}$ Ling Zhang ${ }^{2}$ Yi Chen ${ }^{1}$ Shiyun Shao ${ }^{1}$ Tao Wang ${ }^{3}$ Hongliang Tian $^{3}$ \\ Yingze Shi ${ }^{1}$ Shuxian Wang ${ }^{1}$ \\ ${ }^{1}$ College of Humanities, Sichuan Agricultural University, Ya'an, Sichuan, China \\ ${ }^{2}$ School of Law, Sichuan Agricultural University, Ya'an, Sichuan, China \\ ${ }^{3}$ Human Resources Management Department, The Third Construction Engineering Company LTD. of China \\ Construction Second Engineering Bureau, Beijing, China \\ *Corresponding author. Email:1018784307@qq.com
}

\begin{abstract}
This paper tries to study the impact of farmers' entrepreneurial motivation on entrepreneurial performance, and introduces entrepreneurial ability as a moderating variable to study whether entrepreneurial ability has a moderating effect in this process. On the basis of consulting relevant literature, this paper divides farmers' entrepreneurial motivation into opportunity type and survival type, determines the evaluation indicator of farmers' entrepreneurial performance and entrepreneurial ability, establishes the corresponding evaluation system model, and designs relevant questionnaires. The results show that: (1) There is a significant and positive correlation between entrepreneurial motivation and entrepreneurial performance. (2) Entrepreneurial motivation, work experience and entrepreneurial training have a significant positive impact on entrepreneurial performance. (3) Entrepreneurial ability has a positive moderating effect on the impact of entrepreneurial motivation on entrepreneurial performance.
\end{abstract}

Keywords: Entrepreneurial motivation, Entrepreneurial performance, Entrepreneurial ability.

\section{INTRODUCTION}

Supporting and encouraging farmers' employment and entrepreneurship is an important method and way for China to broaden the incomeincreasing channels of farmers. Especially during the prevention and control of the COVID-19 epidemic, the intention of home-returning farmers to stay in their hometowns to start businesses has greatly increased, farmers' entrepreneurship and innovation are flourishing and the results are remarkable, the entrepreneurial field continues to be expanded, the starting point of entrepreneurship is further elevated, the entrepreneurial service system is being gradually improved, and corresponding supportive measures continue to be strengthened. However, there are still some problems behind the gratifying changes: Due to the constraints of geographical location, economic constraints, and their own quality, the status quo of farmers' entrepreneurship is not ideal. At present, more and more Chinese experts and scholars have begun to study the factors affecting farmers' entrepreneurial performance, such as entrepreneurial motivation, entrepreneurial learning, entrepreneurial environment, entrepreneurial ability, creativity, etc. Among them, entrepreneurial motivation stimulates and maintains farmers' interest and willingness to engage in entrepreneurial activities, and guides farmer entrepreneurs to work towards the established entrepreneurial goals. Existing theories and studies have proved that different types or degrees of entrepreneurial motivation will stimulate different levels of entrepreneurial performance, so this article attempts to study the impact between entrepreneurial motivation and entrepreneurial performance. At the same time, entrepreneurial 
ability, as a link of motivation that affects performance, reflects an individual's estimation of the probability that one's own efforts will promote the achievement of performance goals. This article will also study whether entrepreneurial ability plays a moderating role in the influence of entrepreneurial motivation on entrepreneurial performance.

\section{LITERATURE REVIEW AND RESEARCH HYPOTHESIS}

\subsection{Literature Review}

\subsubsection{Farmers' Entrepreneurial Motivation}

Speaking of the research fever for the root causes of human behavior, since Darwin proposed the theory of evolution, psychologist Woodward [1] proposes motivation (that is, the inner motivation that determined behavior) and applies it to psychology. Amit R and Muller E [2] divide the types of entrepreneurship into push type and pull type. In 1999, Babson College in the United States and the London Business School in the United Kingdom divided the types of entrepreneurship into survival entrepreneurship and opportunity entrepreneurship based on inducement for the first time in 1999. Among them, survival entrepreneurship refers to entrepreneurial behavior that is forced to proceed because there is no other better job option, and opportunity entrepreneurship refers to the entrepreneurial activities spontaneously carried out due to the individual's subjective preferences. Entrepreneurship motivation is the internal driving force that determines entrepreneurial behavior, and farmers' entrepreneurial motivation is one of them. Zeng Zhaoying and Wang Chongming [3] believe that farmers' entrepreneurial motivation can be divided into two types: career achievement type and survival demand type. Other Chinese experts and scholars divide farmers' entrepreneurial motivation into "survival", "employment", "self-realization and development" and "opportunity" categories from different dimensions. According to the more authoritative methods in China and foreign countries, this article divides farmers' entrepreneurial motivation into survival type and opportunity type. Among them, the survival entrepreneurial motivation means that the reason for starting a business is to be forced out of livelihood considerations, such as failing to find a suitable job and supporting a family after unemployment. Opportunity entrepreneurial motivation refers to entrepreneurs who actively discover or create new business opportunities out of the need to realize themselves. At present, the more recognized evaluation indicator system for entrepreneurial motivation, such as the multi-scale developed by Kuratko et al. [4], the five-factor scale developed by Morales-Gualdrón et al. [5], and Duogenzhi and Kuratko et al. [6] proposed a fourfactor structural model of entrepreneurial motivation, which took entrepreneurs' entrepreneurial motivation as the measurement object.

This article divides farmers' entrepreneurial motivation into survival entrepreneurial motivation and opportunity entrepreneurial motivation. Among them, the survival entrepreneurial motivation means that the reason why farmer entrepreneurs start their own businesses is that they can only be forced to start a businesses because they have no other better job options, and opportunity entrepreneurial motivation refers to the fact that farmer entrepreneurs choose to carry out entrepreneurial activities spontaneously and want to achieve self-realization and life breakthroughs through entrepreneurial behavior.

\subsubsection{Farmers' Entrepreneurial Ability}

Entrepreneurship ability is a key determinant that drives entrepreneurs to carry out entrepreneurial activities, and promotes entrepreneurs to achieve expected goals and achieve entrepreneurial success smoothly. Man et al. [7] believe that entrepreneurial ability refers to the ability of entrepreneurs to use entrepreneurial knowledge and skills to create enterprises and operate them successfully. Ma Lan [8] summarizes entrepreneurial ability as a collection of a series of technologies, knowledge and abilities that are conducive to the success of entrepreneurship owned by entrepreneurs, and is an endogenous driving force that is dynamic and continuously growing. Zheng Xiaoyun and others [9] believe that entrepreneurial ability includes opportunity ability and production and operation ability. However, the lack of entrepreneurial ability is an important reason why farmers have difficulty in starting a business. The production and management level of farmers in the process of entrepreneurship and their ability to grasp market opportunities are affected by factors such as personal quality, learning ability, ability to accept information resources, and ability to absorb external knowledge. Wang Manman et al. [10] point out that although skill training courses 
have been carried out in some rural areas, the pertinence and purpose of the courses are not strong, and they are not closely integrated with the actual problems in the entrepreneurial process, and as a result, the enthusiasm of rural entrepreneurs to participate in the training is not high, and the training is difficult to be carried forward. The current evaluation model of entrepreneurial ability includes various dimensions, and the perspectives of analysis are also different, such as the perspective of emphasizing opportunity ability, strategy ability, concept ability and other abilities shown in the entrepreneurial process, the perspective of focusing on the individual level, organizational level, corporate level, team level and other entrepreneurial ability levels, etc.

This article divides farmers' entrepreneurial ability into five dimensions, namely, opportunity ability, tolerance ability, strategy ability, finance ability and management ability, and the corresponding measurement indicators are: the ability to identify potential in the market field, the ability to evaluate potential business opportunities, and the ability to grasp high-quality business opportunities; the tolerance for pressure and change at work, the degree of persistence in adversity, and the principle of personal integrity in the entrepreneurial process; the ability to integrate and link different resources, the ability to formulate and adjust the organization's strategic goals and business ideas, and the ability of re-positioning of the company; the ability to develop financing channels, the diversity of financing methods, and the financial support of the government; the ability to manage employees, allocate organizational resources reasonably, maintain necessary interpersonal relationships, and solve problems in a timely manner.

\subsubsection{Farmers' Entrepreneurial Performance}

Entrepreneurship performance refers to the extent to which entrepreneurs achieve the expected goals of entrepreneurship. The current entrepreneurial performance theory is mainly based on the research results of organization and strategic management, covering resource-based theory, process theory and goal theory. Entrepreneurship performance can be measured by the degree of completion of goals, which can also be measured by specific entrepreneurial behavior and be judged by the ability of entrepreneurs to obtain and possess scarce resources. Since the 1970s, foreign scholars have begun to conduct research on entrepreneurial performance, and the construction of the evaluation indicator system has been relatively complete. There are different research perspectives or different indicator systems for different research purposes in relevant Chinese researches. Xu Xiurui and Tian Shanwu [11] point out that researchers usually tend to use a combination of financial and non-financial indicators to measure entrepreneurial performance. Zhang Chengsu [12] believes that personal income, family income, living standards, social status, satisfaction with one's own entrepreneurship, and achievement of preentrepreneurship goals can be used as indicators to measure entrepreneurship performance.

This article divides farmers' entrepreneurial performance into five dimensions, namely "expected goals", "overall satisfaction", "profit level", "rate of return on investment" and "sales status", comprehensively evaluating the completion of the goals set by farmers in the process of entrepreneurship, the satisfaction of the current work, whether the profit level obtained is good, the economic return obtained through venture capital investment and the sales status in a certain period of time, which can objectively and fairly reflect the overall level of farmers' entrepreneurial performance.

\subsubsection{Research on the Impact of Entrepreneurship Motivation on Entrepreneurship Performance}

More and more scholars believe that entrepreneurial performance is determined by the interaction of multiple factors, rather than a single factor. Among them, Krauss et al. [13] believe that entrepreneurial motivation has a significant impact on entrepreneurial performance. Afterwards, the idea that entrepreneurial motivation has a positive impact on entrepreneurial performance has also been proposed. Huang Baodong [14] believes that the stronger the motivation, the more significant the performance improvement. Wang Huafeng [15] believes that different types of entrepreneurial motivation have different effects on entrepreneurial performance. Xu Zhandong et al. [16] believe that the connotation of entrepreneurial performance is the degree of completion of entrepreneurial goals. When it focuses on survival motivation, it pays more attention to the acquisition of money to make a living, and when it focuses on opportunity motivation, it pays more attention to raising reputation and sense of self-worth. Liang $\mathrm{Xi}$ [17] 
believes that the higher the level of entrepreneurial motivation, the better the entrepreneurial performance. Compared with farmers of survival type, opportunity entrepreneurial farmers have better entrepreneurial performance. Cheng Jianqing [18] and others believe that entrepreneurial motivation has a positive impact on entrepreneurial performance, thereby enhancing the sense of subjective well-being. More subjective and positive entrepreneurial motivation can further enhance entrepreneurs' entrepreneurial competence by stimulating the inherent potential of entrepreneurs, and help entrepreneurs integrate multiple resources for relearning and enhance their own entrepreneurial ability. All in all, entrepreneurial motivation can inspire entrepreneurial passion and initiative, help entrepreneurs find their entrepreneurial goals, and guide them to constantly approach the established goals, thereby further affecting entrepreneurs' performance to a certain extent. Therefore, this article attempts to study the impact of entrepreneurial motivation on farmers' entrepreneurial performance, which not only has important theoretical significance, but also has practical value that can't be ignored.

\subsubsection{The Moderating Effect of Entrepreneurial Ability}

The influence of farmers' entrepreneurial motivation on entrepreneurial behavior is affected by a variety of other factors, which will lead to different effects and even play a decisive role. This means that performance is the result of behavior and is also affected by other factors. The comprehensive incentive model of Porter and Lawler is shown in "Figure 1". The link from motivation to performance reflects the individual's estimation of the possibility that his own efforts will promote the achievement of performance goals. "Expectation and goal" and "ability" as two mitigating conditions strengthen this link process. The combination of goal and ability determines the degree to which motivation is successfully transformed into performance, which means that the influence of motivation on performance depends on two moderating factors: expectation and goal, and ability.

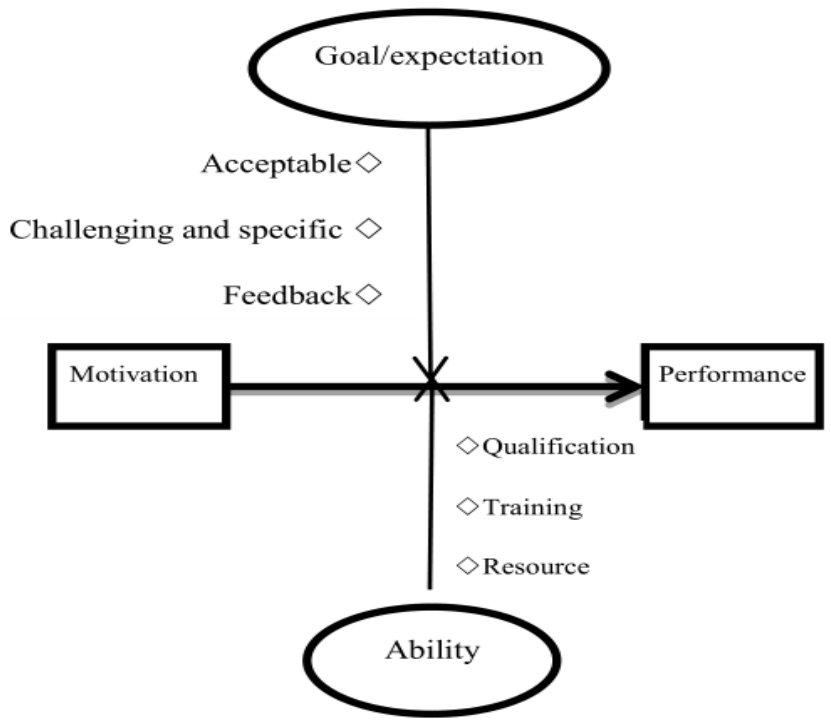

Figure 1 Comprehensive incentive model.

Ma Lan [19] believes that entrepreneurs with entrepreneurial ability have a strong ability to identify opportunities and use resources in the entrepreneurial process and growth process. The improvement of this entrepreneurial ability is the result of innovation-driven iterative ideas, transformation of ideas, diffusion of ideas and implementation of ideas. If an entrepreneur simply has entrepreneurial motivation, it doesn't necessarily mean that he has a higher entrepreneurial performance, which is also affected by factors such as entrepreneurial environment and entrepreneurial ability. Jiang Shiyao [20] believes that the absorptive ability of entrepreneurs plays a moderating role between entrepreneurs' adjustment of focus and iterative innovation. This article believes that entrepreneurial ability will gradually improve with the accumulation of experience and 
lessons in the entrepreneurial process, but the specific speed and level of improvement will be determined according to the entrepreneur's own situation and the objective environment of entrepreneurship. At the same time, through various methods such as skill training, theoretical study, social practice, etc., the effect of enhancing entrepreneurial ability can be achieved.

\subsection{Research Hypothesis}

Based on related concepts, this article deduces the relationship between various variables, draws a
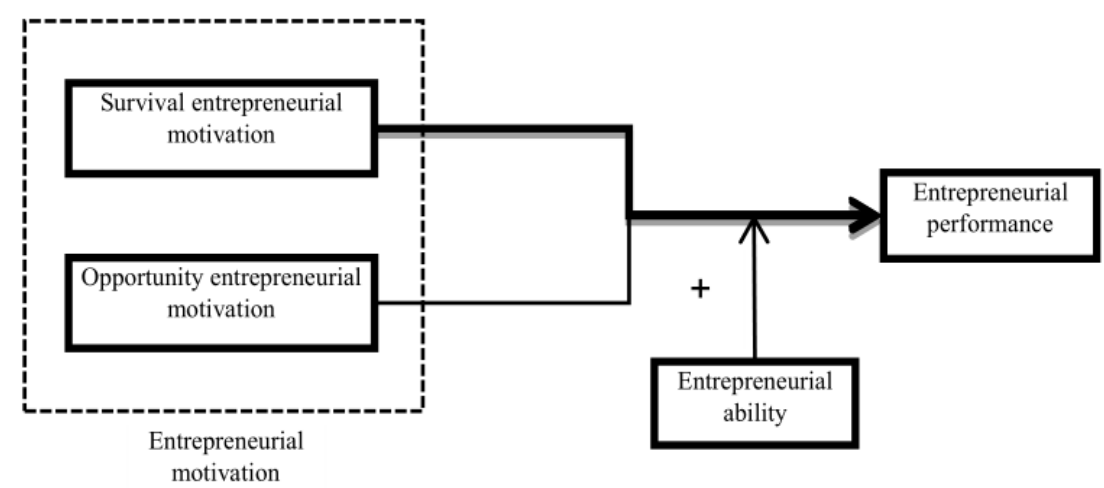

Figure 2 Research model diagram.

\section{RESEARCH DESIGN}

\subsection{Questionnaire Design}

In this article, the following questionnaire is designed according to the "survival" and "opportunity" entrepreneurial motivation of farmers and the constructed entrepreneurial performance indicators and entrepreneurial ability indicators of farmers. The questionnaire mainly revolves around two parts: background information and entrepreneurship survey. In the background information, it mainly collects information on the interviewee's gender, age, educational background, whether he or she has been engaged in entrepreneurial activities, whether he or she has work experience in related industries, and whether he or she has participated in entrepreneurial-related training and so on. In the survey of entrepreneurship, this article divides entrepreneurial motivation into "survival type" and "opportunity type", and four questions are designed respectively; the entrepreneurial performance is designed into five questions according to pre-defined indicators; the entrepreneurial ability is designed into five dimensions according to pre-defined indicators, with a total of eleven questions. Meanwhile, the research model as shown in "Figure 2", and puts forward the following hypotheses:

- H1: Entrepreneurship motivation has a positive impact on entrepreneurial performance

- H2: Entrepreneurship ability has a moderating effect in the influence of entrepreneurial motivation on entrepreneurial performance options of questionnaire questions are divided into five dimensions based on the "Likert scale" according to the degree of conformity with the questions. The questionnaire is detailedly shown in the appendix.

\subsection{Research Method}

\subsubsection{Descriptive Research Method}

Based on a full understanding of entrepreneurial motivation, entrepreneurial ability, entrepreneurial performance and other related theories, it combines existing data, phenomena and laws with own understanding and verification, and expounds them through descriptions.

\subsubsection{Qualitative Analysis Method}

It uses methods such as induction, deduction, analysis, and generalization to analyze the influence mechanism of farmers' entrepreneurial motivation on entrepreneurial performance and the moderating role of entrepreneurial ability, and build related framework models. 


\subsubsection{Experience Summary Method}

It conducts specific analysis, induction and deduction of the actual situation, summarizes it into a more systematic theoretical expression, and refines recommendations with promotion and application value.

\subsubsection{Questionnaire Survey Method}

It collects and analyzes data by designing reliable scientific questionnaires for reliability and validity testing.

\subsection{Research Idea}

Based on the perspective of human resource management, this article attempts to study and analyze the impact of farmers' entrepreneurial motivation on entrepreneurial performance and introduce the entrepreneurial ability of farmers as a moderating variable so as to test whether entrepreneurial ability plays a moderating role in the influence of motivation on performance. Based on this idea, this article divides entrepreneurial motivation into survival entrepreneurial motivation and opportunity entrepreneurial motivation from the deep-seated internal factors. On the basis of reference to relevant literature, it determines the evaluation indicator and system of farmers' entrepreneurial performance and entrepreneurial ability, establishes an evaluation system model for farmers' entrepreneurial performance and entrepreneurial ability, designs a related questionnaire, strictly follows the questionnaire design process, and uses questionnaire survey to obtain data and information. On the premise of obtaining sufficient and effective research data, it uses correlation analysis and regression analysis to analyze the data relationship between entrepreneurial motivation and entrepreneurial performance, conduct an analysis of the moderating effect of the influence of entrepreneurial ability in this process, and then draw relevant conclusion and enlightenment.

\subsection{Research Sample}

This research uses the "New-type Professional Farmer" training class of Sichuan Agricultural University as a platform. A questionnaire survey was conducted on farmer entrepreneurs in Chengdu, Bazhong, Ya'an and other regions of Sichuan by issuing paper questionnaires, and a total of 207 valid questionnaires were collected. The sample distribution characteristics are shown in "Table 1".

"Table 1" gives the sample size, percentage and average score on entrepreneurial performance of the six individual characteristic variables of sample gender, age, education background, entrepreneurial experience, work experience, and entrepreneurial training. Among them, men in the sample account for more than $70 \%$. The sample age is mostly distributed in the 41-50 years old, and the farmer entrepreneurs aged 25 and below and 51 and above are few. Most people in the sample have high school or junior college diploma. Most of the samples have had entrepreneurial experience, industry work experience and experience of attending training. According to the results of descriptive statistical analysis, the average scores of men and women in entrepreneurial performance are not much different. Age has a greater impact on entrepreneurial performance, of which farmers aged 25 and below have the highest average score for entrepreneurial performance, which is 3.3778 , and farmers aged 51 and above have the lowest average score for entrepreneurial performance, which is 2.9800. The educational background, entrepreneurial experience, and industry work experience of farmer entrepreneurs have no obvious influence on entrepreneurial performance. The average entrepreneurial performance scores of untrained farmers are higher than those of trained farmers, with a score of 3.3568 . 
Table 1. Sample characteristic distribution $(\mathrm{N}=207)$

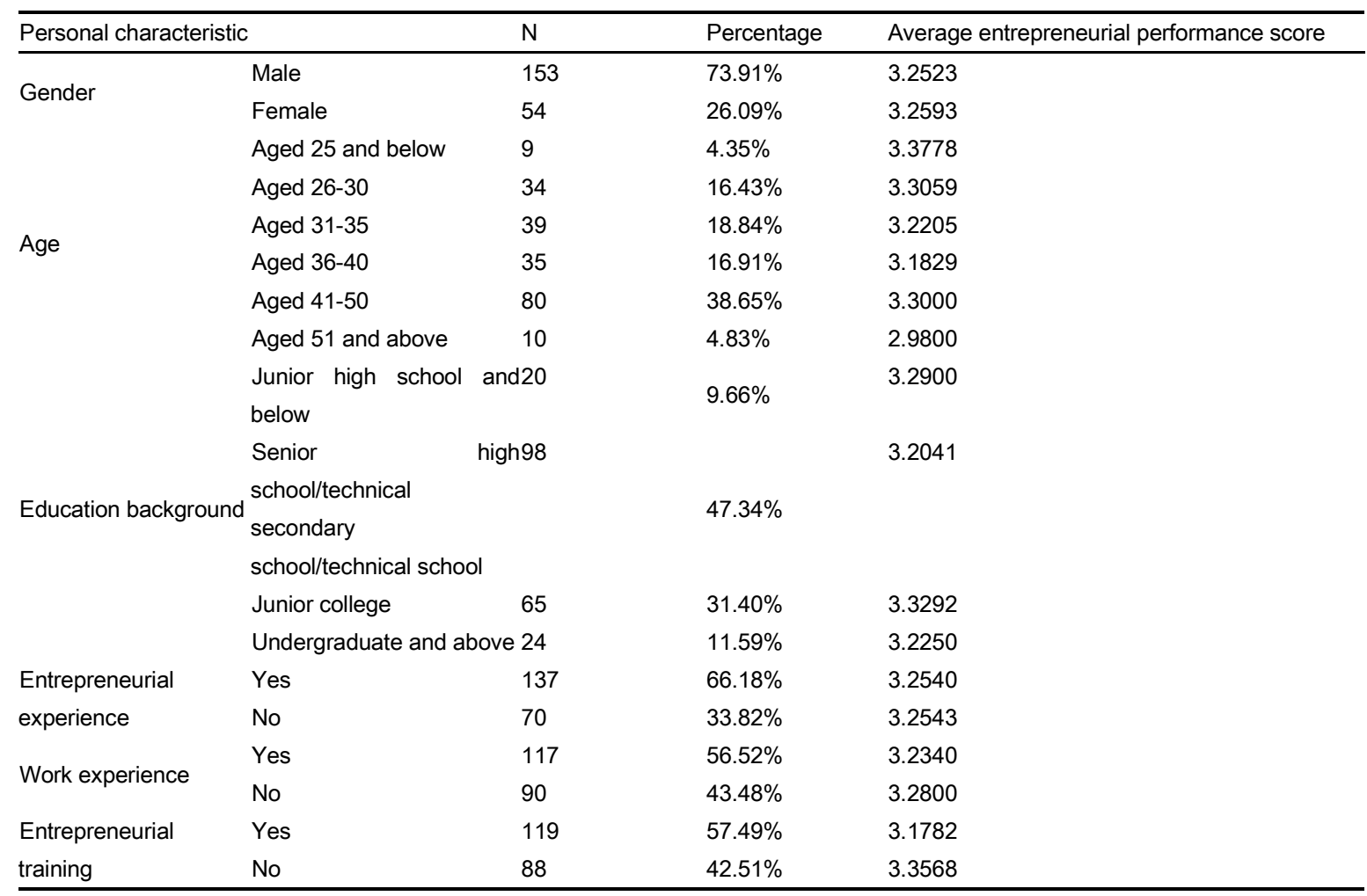

\section{DATA ANALYSIS}

\subsection{Descriptive and Correlation Analysis}

"Table 2" gives the average, standard deviation and correlation coefficient of five variables: survival entrepreneurial motivation, opportunity entrepreneurial motivation, entrepreneurial motivation, entrepreneurial ability and entrepreneurial performance. The results show that from the perspective of the average value, the entrepreneurial motivation of farmer entrepreneurs is more biased towards opportunity entrepreneurial motivation. In addition, farmer entrepreneurs generally have high entrepreneurial motivation, but the performance of entrepreneurial ability and entrepreneurial performance on the mean value is low. From the perspective of the correlation coefficient, the survival entrepreneurial motivation and entrepreneurial performance have a significant correlation at the 0.01 level (two-tailed), opportunity entrepreneurial motivation and entrepreneurial performance are significantly correlated at the 0.05 level (two-tailed), and entrepreneurship motivation and entrepreneurial performance are significantly correlated at the 0.01 level (two-tailed), and all of them are positively correlated. 
Table 2. The average, standard deviation and correlation coefficient of each variable

\begin{tabular}{|c|c|c|c|c|c|c|c|}
\hline Variable & Average & $\begin{array}{l}\text { Standard } \\
\text { deviation }\end{array}$ & $\begin{array}{l}\text { Survival entrepreneurial } \\
\text { motivation }\end{array}$ & $\begin{array}{l}\text { Opportunity } \\
\text { entrepreneurial } \\
\text { motivation }\end{array}$ & $\begin{array}{l}\text { Entrepreneurial } \\
\text { motivation }\end{array}$ & $\begin{array}{l}\text { Entrepreneurial } \\
\text { ability }\end{array}$ & $\begin{array}{l}\text { Entrepreneurial } \\
\text { performance }\end{array}$ \\
\hline \multicolumn{8}{|l|}{ Survival type } \\
\hline $\begin{array}{l}\text { Entrepreneurial } \\
\text { motivation }\end{array}$ & 4.0217 & 0.73538 & 0.720 & & & & \\
\hline \multicolumn{8}{|l|}{ Opportunity type } \\
\hline $\begin{array}{l}\text { Entrepreneurial } \\
\text { motivation }\end{array}$ & 4.3780 & 0.66731 & $0.433^{* *}$ & 0.814 & & & \\
\hline $\begin{array}{l}\text { Entrepreneurial } \\
\text { motivation }\end{array}$ & 4.1999 & 0.59400 & $0.862^{* *}$ & $0.830^{* *}$ & 0.800 & & \\
\hline $\begin{array}{l}\text { Entrepreneurial } \\
\text { ability }\end{array}$ & 3.7726 & 0.54705 & $0.148^{*}$ & $0.336^{* *}$ & $0.280^{* *}$ & 0.892 & \\
\hline $\begin{array}{l}\text { Entrepreneurial } \\
\text { performance }\end{array}$ & 3.2541 & 0.75077 & $0.181^{* *}$ & $0.166^{*}$ & $0.205^{\star *}$ & $0.471^{* *}$ & 0.860 \\
\hline
\end{tabular}

\subsection{Regression Analysis}

It can be seen from Model 1 of "Table 3" that, taking entrepreneurial performance as the dependent variable, the gender, age, educational background, entrepreneurial experience, work experience, and entrepreneurial training of individual characteristic variables are introduced into the regression equation as control variables, and the results show that the regression coefficient of the control variable work experience $(\beta=0.197$, $\mathrm{p}<0.01)$ is significant. According to Model 2, taking entrepreneurial performance as the dependent variable, after putting the control variable and entrepreneurial motivation into the regression equation, the regression coefficient of the control variable work experience $(\beta=0.163$, $\mathrm{p}<0.05)$, the regression coefficient of entrepreneurship training $(\beta=0.158, p<0.05)$ and the regression coefficient of the independent variable entrepreneurial motivation $(\beta=0.177, p<0.05)$ are all significant. According to the regression results, entrepreneurial motivation has a significant positive impact on entrepreneurial performance. Data analysis also shows that work experience in related industries and experience in entrepreneurship training also have a significant positive impact on entrepreneurial performance. Combined with the integrated model theory of improving motivation mentioned in the previous part, this shows that in addition to entrepreneurial motivation, the improvement of entrepreneurial ability brought by work experience and entrepreneurial training to farmer entrepreneurs is also an important moderating factor that affects entrepreneurial performance. In order to further study whether entrepreneurial ability has a moderating effect in the influence of entrepreneurial motivation on entrepreneurial performance, this article will introduce entrepreneurial ability as a moderating variable to test the results. 
Table 3. Variable regression analysis

\begin{tabular}{|c|c|c|}
\hline Variable & Entrepreneurial performance & \\
\hline & Model $1(\beta)$ & Model $2(\beta)$ \\
\hline \multicolumn{3}{|l|}{ Control variable } \\
\hline Gender & 0.003 & -0.020 \\
\hline Age & -0.050 & -0.013 \\
\hline Education background & -0.111 & -0.087 \\
\hline Entrepreneurial experience & -0.010 & -0.040 \\
\hline Work experience & $0.197^{* *}$ & $0.163^{*}$ \\
\hline Entrepreneurial training & 0.133 & $0.158^{*}$ \\
\hline \multicolumn{3}{|l|}{ Independent variable } \\
\hline \multicolumn{3}{|l|}{ Entrepreneurial motivation } \\
\hline $\mathrm{R}^{2}$ & 0.053 & 0.077 \\
\hline$\triangle \mathrm{R}^{2}$ & & 0.028 \\
\hline F-value & $2.932^{* *}$ & $3.461^{*}$ \\
\hline$\Delta \mathrm{F}$ & & 6.181 \\
\hline
\end{tabular}

a Note: $*$ means $\mathrm{p}<0.05, * *$ means $\mathrm{p}<0.01 ;$ the numeric value in the table is the standardized regression coefficient.

\subsection{Test of the Moderating Effect of Entrepreneurship Ability}

"Table 4" examines the moderating effect of entrepreneurial ability in the process of motivation affecting performance. In the regression results of the model with entrepreneurial performance as the dependent variable and entrepreneurial motivation, entrepreneurial ability, and the product of

Table 4. Test results of the moderating effect of entrepreneurial ability between entrepreneurial motivation and entrepreneurial performance

\begin{tabular}{|c|c|c|c|c|}
\hline \multirow{2}{*}{ Variable } & \multicolumn{4}{|c|}{ Entrepreneurial performance } \\
\hline & $\beta$ & SE & $\mathrm{t}$ & $\mathrm{p}$ \\
\hline Constant & 5.222 & 2.175 & 2.401 & 0.017 \\
\hline Entrepreneurial ability & -0.653 & 0.582 & -1.122 & 0.263 \\
\hline Entrepreneurial motivation $\times$ Entrepreneurial ability & 0.305 & 0.138 & 2.205 & 0.029 \\
\hline
\end{tabular}

\section{CONCLUSION}

This article takes entrepreneurial motivation as an independent variable, entrepreneurial performance as a dependent variable, and entrepreneurial ability as a moderating variable, constructing a model of the influence of entrepreneurial motivation on entrepreneurial performance and a model of the mechanism of action of entrepreneurial ability as a moderating variable. This article clarifies entrepreneurial motivation as the reason and guidance for farmers' internal entrepreneurship. Both survival entrepreneurial motivation and opportunity entrepreneurial motivation and entrepreneurial ability as independent variables, the regression coefficient of the product of entrepreneurial motivation and entrepreneurial ability is significant and is not $0(\beta=0.305, p=0.029))$, indicating that the influence of entrepreneurial motivation on entrepreneurial performance is positively regulated by entrepreneurial ability. 
advantages and benefits of farmers' entrepreneurship, mobilize the enthusiasm and subjective initiative of farmers to start a business, and attract and call on more farmers to become emerging entrepreneurs. For farmers who have started entrepreneurship or farmers who already have entrepreneurial motives and ideas, local governments should publicize the latest economic, legal, technological, and taxation policies related to farmers' entrepreneurship, so as to help farmer entrepreneurs understand entrepreneurial information more quickly and comprehensively.

\subsection{Implementing Supporting Policies}

Local governments should actively respond to the call of the state, fully implement relevant supporting policies for farmers' entrepreneurship, introduce specific representative and regional exclusive measures according to local actual conditions, vigorously establish local supporting projects, and provide substantive assistance to farmers' entrepreneurship in financial lending, human resources, and industrial poverty alleviation.

\subsection{Strengthening the Effectiveness of Training}

In contemporary society, entrepreneurship by farmers has become a common phenomenon, and more and more experts and scholars have studied farmers as a profession. Compared with other entrepreneurs, farmer entrepreneurs have a certain degree of particularity, and they are usually lacking in terms of education background, experience and management. Therefore, local governments should pay attention to the improvement of entrepreneurial learning ability and skills of farmer entrepreneurs, combine with theoretical cultivation systems such as "New-type Professional Farmer", and organize and create professional training class to continuously improve the entrepreneurial ability of farmer entrepreneurs.

\subsection{Perfecting Infrastructure}

Chinese farmers' entrepreneurship has always been restricted by issues such as regional transportation, infrastructure, and resource barriers, which has caused some farmers with entrepreneurial motivation to give up entrepreneurship or fail to achieve high entrepreneurial performance due to the impact of the entrepreneurial environment. Therefore, rural areas should accelerate the construction of rural infrastructure, promote farmers' innovation and entrepreneurship, improve and enrich farmers' "innovative and entrepreneurial" service projects, and build a more sound service system.

\subsection{Implementing Precise Assistance}

Through investigation, it is found that the actual situations and problems encountered by farmer entrepreneurs in the process of starting a business are not the same. The single theoretical knowledge can only solve a part of the macroscopic problems in general. However, specific problems still need to be solved through specific case analysis and even one-to-one assistance. For example, through effective measures such as the "Thousands of Enterprises Helping Thousands of Villages" platform or the selection of leaders for becoming rich in rural areas, it can further achieve precise assistance for farmers' entrepreneurship and improve the current level and quality of farmers' entrepreneurship.

\section{AUTHORS' CONTRIBUTIONS}

Qinjuan Li wrote and revised the paper, Ling Zhang wrote the paper, Yi Chen was responsible for data analysis, Shiyun Shao was responsible for literature review, Tao Wang and Hongliang Tian were responsible for collating data using software, and Yingze Shi and Shuxian Wang were responsible for collecting data.

\section{REFERENCES}

[1] AMIT R, MULlER E. "Push" and "Pull" Entrepreneurship $[\mathrm{J}]$. Journal of Small Business, 1995,12(4):64-80.

[2] KraussSI Frese M. Friedrich C ct al Entreprencurial orientation A psychological model of success among southem African small business owners [0] European Journal of Work and Oganizational Psychology. Volume 14. 2005. 14(3).315-344.

[3] Man T W Y, Lau T, Chan K F. The competitiveness of small and medium enterprises: A conceptualization with focus on entrepreneurial competencies [J]. Journal of Business Venturing, 2002, 17(2): 123-142

[4] Paul D. Reynolds, S. Michael Camp, William D. Bygrave, Erkko Autio, Michael Hay. Global Entrepreneurship Monitor 2001 
Summary Report. 2002 London Business School and Babson College [02April02].18

[5] Cheng Jianqing, Luo Jinlian, Li Shuwen, Yan Jiaqi, Zhong Jing. Entrepreneurial Motivation and Entrepreneur's Subjective Well-Being: The Moderating Effect of Social Norm [J]. Science \& Technology Progress and Policy, 2020, 37(06): 46-52. (in Chinese)

[6] Duan Jinyun, Wang Peng, Zhu Yuelong. Entrepreneurial Motivation Research: Conceptual Structure, Influence Factors and Theoretical Models [J]. Advances in Psychological Science, 2012, 20(05): 698-704. (in Chinese)

[7] Fan Bowen, Ying Wangjiang. Farmers Entrepreneurial Motivation and Its Transformation Path [J]. Modern Economic Research, 2020(07): 123-132. (in Chinese)

[8] Huang Baodong. Research on the Relationship Among Personality Trait, Entrepreneurship Motivation, Entrepreneurship Strategy and Entrepreneurship Performance: Taking Taiwanese SME entrepreneurs as an example [D]. Taiwan: National Cheng Kung University, 2006. (in Chinese)

[9] Jiang Shiyao. Research on iterative innovation mechanism based on the perspective of "motivation-ability" of entrepreneur [J]. Studies in Science of Science, 2020, 38(09): 1698-1705. (in Chinese)

[10] Kang Shuhua, Wang Dai, Feng Shuliang. Criminology Dictionary. Gansu People's Publishing House, 1995-0. (in Chinese)

[11] Li Lei, Wang Xiaojie. Gender Differences in Entrepreneurship* — A Research Based on the Perspective of Entrepreneurship Motivation

[12] Liu Wei, Yong Min, Deng Rui. A Multiplecase Study on Transformation from Peasant Entrepreneurship to Agricultural Entrepreneurship [J]. China Soft Science, 2018(06): 105-118. (in Chinese)

[13] Liang Xi. Research on Farmers' Entrepreneurship Motivation and Its Impact on Entrepreneurship Performance [D]. Jiangxi Agricultural University, 2018. (in Chinese)

[14] Ma Lan. The impact of innovation drive and entrepreneurial ability of new ventures on corporate growth performance - a mediating role [J]. Enterprise Economy, 2019(09): 49-59. (in Chinese)

[15] Wang Huafeng, Xie Congxuan, Research on the relationship between entrepreneurial motivation and entrepreneurial performance of college students, Journal of Guangzhou University (Social Science Edition), 2014.130:39-44. (in Chinese)

[16] Wang Manman, Fu Rui, Shi Qiuxia. Research on the entrepreneurial ability of rural entrepreneurs from the perspective of "one village, one product" industry development Based on field surveys in three villages in northern Anhui [J]. Pioneering With Science \& Technology Monthly, 2020, 33(09):18-21. (in Chinese)

[17] Xu Xiurui, Tian Shanwu. A Review of Research on Entrepreneurial Performance [J]. Value Engineering, 2017, 36(16): 34-35. (in Chinese)

[18] Xu Zhandong, Mei Qiang, Li Hongbo, Yang Daojian, Li Hui. Research on the Relationship Among university students' Entrepreneurship Environment, Entrepreneurship Motivation and New Venture Performance. Science and Technology Management Research, 201Y 37(9):147-154. (in Chinese)

[19] Yu Shaozhong. A Review of Researches on Entrepreneurial Performance [J]. Foreign Economics \& Management, 2013, 35(02): 3442+62. (in Chinese)

[20] Yuan Shuai. Research on the relationship among internal entrepreneurial motivation, entrepreneurial learning and entrepreneurial performance [D]. Nanjing University of Posts and Telecommunications, 2020. (in Chinese)

[21] Zhang Chengsu. Relationships Between Double Capital, Entrepreneurial Ability and Entrepreneurial Performance of Land-lost Farmers [J]. Guizhou Agricultural Sciences, 2020, 48(02): 162-167. (in Chinese)

[22] Zhu Honggen, Jiang Huizhen, Kang Lanyuan. Influence of Entrepreneurial Environment on Farmers' Entrepreneurial Efficiency — Based on Empirical Analysis of DEA-Tobit Model [J]. Commercial Research, 2015(03): 112-118. (in Chinese) 
[23] Zheng Xiaoyun, Qi Diming, Mao Weiqing. The Influence of Relationship Embeddedness and Resource Availability on Farmers' Entrepreneurial Ability — Empirical Analysis Based on the Sample of Farmers' Entrepreneurship in Zhejiang Province [J]. Liaoning Agricultural Sciences, 2020(02): 1622. (in Chinese)

[24] Zhang Yingliang, Tang Li. Study on Factors Affecting Farmers' Entrepreneurial Performance - Based on Survey of 284 Samples in Eastern Region of China [J]. Journal of Huazhong Agricultural University (Social Sciences Edition), 2013(04): 19-24. (in Chinese)

[25] Zeng Zhaoying, Wang Chongming. The investigation of Chinese entrepreneurial motivation [J]. Science and Technology Management Research, 2009, 29(09): 285-287. (in Chinese) 